Article

\title{
Emerging Location-Based Service Data on Perceiving and Measuring Multifunctionality of Rural Space: A Study of Suzhou, China
}

\author{
Yuan Yuan ${ }^{1}$, Hongbo $\mathrm{Li}^{1,2, *}$, Xiaolin Zhang ${ }^{1,2}$, Xiaoliang $\mathrm{Hu}^{1}$ and Yahua Wang ${ }^{1,2}$ \\ 1 College of Geographical Science, Nanjing Normal University, Nanjing 210023, China; \\ nnuyuany@163.com (Y.Y.); xiaolin-zh@163.com (X.Z.); huxiaoliang001@126.com (X.H.); \\ 09123@njnu.edu.cn (Y.W.) \\ 2 Jiangsu Provincial Key Laboratory for Numerical Simulation of Large Scale Complex Systems, \\ Nanjing Normal University, Nanjing 210023, China \\ * Correspondence: lihb@njnu.edu.cn
}

Received: 29 September 2019; Accepted: 18 October 2019; Published: 22 October 2019

\begin{abstract}
Understanding how human mobilities reconstruct contemporary rural space is of great significance to multifunctional rural transition. However, conventional approaches adopted by social surveys have a technological restriction on collecting data of individual behavior, such as limited samples, subjective self-reported data, and time-consuming investigation. This study proposes a data-driven methodology to explore multifunctionality of rural space by employing the real-time Tencent user quantity (RTUQ) data to analyze the quantity and distribution of observables in rural space. Based on over 250,000 records of hourly RTUQ data during a one-week research period, we perceive spatiotemporal variation of human mobilities in three differentiated villages in Suzhou, China, as well as measure function of residence, employment and consumption on holidays, weekdays and weekends using original equations of function index. Results show that the RTUQ data is valid and reliable for perceiving dynamic patterns of human mobilities at village level, as well as offering new implication for transitional pathways of decision-making. The proposed method is proved to be suitable for distinguishing and comparing multifunctionality of rural space in various times and places, future research on exploring contemporary rural space towards multifunctionality with more geospatial big data is put forward.
\end{abstract}

Keywords: multifunctionality; RTUQ data; function index; human mobilities; patterns; Suzhou

\section{Introduction}

As evidenced in a substantial body of research and commentary on multifunctional rural development both in global North and South [1-5], a strong attention on diversity rather than homogeneity and an awareness of the inside-outside dynamic in shaping contemporary rural space are taken as the main relevant features of rural studies [6-8]. As early as the 1990s, academic allusions were made to multifunctional issues linked to "noneconomic objectives" of agriculture, pluriactivity, and diversification in European countries [9]. For example, Marsden suggested the emergence of four ideal types within a "differentiated countryside" with reference to the British case [10]. However, Wilson criticized the productivist and post-productivist agricultural regimes have been conceptualized from a UK-centric perspective, whether the concept has wider applicability within Europe and beyond is still in doubt [11]. Since then, a more holistic view of multifunctionality has emerged that places more emphasis on the interlinkages of the concept with rural development, culture, the consumption countryside, societal needs, agency-led patterns, and processes of agricultural and rural change, as well as environmental issues. Holmes expressed a preference for an alternative concept and 
nomenclature, described as a multifunctional rural transition, and argued that the multifunctional transition involves a radical reordering in the three basic purposes underlying human use of rural space, namely production, consumption, and protection [12]. Moreover, Woods examined the reconstitution of rural places under the processes of globalization, highlighting that the interaction of local and global actors, and of human and non-human actants, has produced new hybrid forms and relations of rural space [13]. To understand the contemporary rural space within extreme diversity, Halfacree suggested a three-fold model of rural space, which has three facets, rural locality, representations of the rural, and lives of the rural [14]. Specifically, he emphasized that everyday lives of the rural are inevitably incoherent and fractured, and incorporate individual and social elements in their cognitive interpretation and negotiation. From this viewpoint, exploring multifunctionality of rural space means looking at how individuals and groups mobilize their resources and activate alliances to impose their social representations of rurality or to change the existing ones [15-17].

Although the dominant spatial focus of research has been very much on urban places, we argue that the rural space, especially in the process of multifunctional transition, constitutes an extremely interesting case study of contemporary mobilities. However, conventional approaches in related studies, such as recall method and activity diary adopted by time geography, have methodological shortages and technological restricts to collect data of individual space-time behavior, highly dependent on the cooperation of respondents, and an inevitable situation of error logging and information missing [18-20]. Another problem is that field investigation requires tremendous time and funding, which limits the amount of collected samples, let alone the validity and reliability of the self-reported or observed data. The last two decades has witnessed the rapid development of GIS, which prominently promoted new methods of collecting spatial-temporal data, managing behavior data and representing human activity patterns [21,22]. Further, recent emergence of geographic big data, e.g., location-aware technologies (LAT) data [23] and location-based services (LBS) data [24], has created an emerging research stream, especially in interdisciplinary fields of big data and human geography including, in particular, urban computing and social sensing [25-27], which offers a new opportunity for human geography study within multi-scales. For example, mobile phone signaling data [28,29], smart card of bus/metro data, and taxi GPS trajectory data [30,31] are used to explore mobility patterns on macro-scale, social media data, POI data [32,33], and Google Maps [34,35] are new-style tools for vitality assessment of activities on micro-scale such as in a community level. A growing body of research regards application of big data analyzing human mobility; however, most existing studies are limited in urban areas [36] and ignore contemporary rural spaces as an important case study area for geographic big data application.

Thus, this study aims at perceiving and measuring multifunctionality of rural space in three typical villages in Suzhou, China, using the emerging LBS data. There is a main methodological goal and a secondary empirical goal. The main goal is to explore the application of LBS data to measure multifunctionality by building function index of rural space; the empirical goal is to reveal spatiotemporal patterns of human activities and their influence on the decision-making mechanisms of rural development trajectories.

\section{Materials and Methods}

\subsection{Study Area}

Suzhou is a prefecture-level city in the core area of the Yangtze River Delta region, connecting Shanghai to the east. With a history of more than 2500 years, Suzhou shows some differences from other documented Chinese cities in its development trajectory towards modernization and urbanization, whose economic restructuring is heavily driven by globalization and the influx of FDI [37,38], and it has been transformed from a famous national commercial city in history to an industrial base of Shanghai [39], as well as one of the best eco-cities globally [40]. Meanwhile, rural areas in Suzhou have also undergone a long history of diversified and complex patterns of evolution [41], which has been unprecedentedly shaped by factors such as significant rural-to-urban migration [42,43], the legacy of a 
strong township and village enterprises (TVEs)-based industrialization, and domestic mass tourism development $[44,45]$. Therefore, it represents an extreme example of multifunctional rural transition in China.

Since the reform and opening up, China's urban-rural relationship has undergone a profound transformation from binary opposition to integrated development. In the 1980s, the bottom-up Sunan (Southern Jiangsu Province) mode promoted the rapid replacement of agriculture by township and village enterprises (TVEs) and became the mainstay of rural economic development and off-farm employment [46], caused a "deagrarianization" process in Suzhou's rural areas. In the mid-1990s, the driving force of economic development experienced a major change by the export-oriented economic development mode driven by foreign investment, which led to a major recession of rural industries. To solve problems of traditional TVE-based economy, such as small scale, low efficiency, and scattered distribution, local governments set a goal of combining rural industrialization and rural urbanization. This approach required TVEs to concentrate in industrial parks and economic development zones [47,48]. Since 2000, a series of ecological and residential environment management initiatives have been carried out by the local government in rural areas echoing national policies, such as payments for ecosystem services and farmland eco-compensation schemes [49,50]. At the same time, developing rural tourism services was also encouraged to adjust and optimize rural industrial structures, extend the agricultural industrial chain, promote nonagricultural employment, and increase the incomes of villagers in rural areas with tourism resources [51]. As a result, the pattern, elements, structure, and organizational relationship of rural space have shown a tendency toward accelerated reconstruction. The differential tendency from homogeneity toward heterogeneity thus becomes more apparent. Many villages have urbanized; some of them more so than towns. However, other villages have begun to transform towards specialization, such as historical and culturally protected villages, tourism villages, industrial villages, and modern agricultural villages. Additionally, other villages have experienced outward expansion with internal and hollow structures, thus acquiring the moniker "hollow villages" and garnering significant attention from academics and practitioners. The remaining villages are facing recession and extinction because of massive population losses. According to the latest statistical yearbook, the total resident population in Suzhou has increased from 5.27 million in 1982 to 10.68 million in 2017 with an urbanization rate from $20.52 \%$ to $75.50 \%$. Meanwhile, it had a per capita GDP of more than $\$ 24,000$ - the fourth highest in mainland China—and a per capita disposable income of the rural residents around $\$ 4440$, only half the urban residents' level, also one of the lowest cities in the mainland.

Three typical villages were selected as case areas in this study, namely, Luxiang, Zhonganqiao and Jishan, each with unique characteristics in terms of location conditions, geographical landscapes, and development modes (Figure 1). Among them, Luxiang is located in the Tai Lake scenic area, far from the city. This area has four distinct seasons, pleasant climate, fertile lands, and abundant resources. Local villagers are mainly occupied in fruit tree and tea planting and freshwater aquaculture. Besides, Luxiang is one of the first Historical and Cultural villages in China, including an ancient hamlet (AH) with a history going back more than 800 years, which has been preserved in good condition, attracting a large number of domestic tourists. In recent years, local villagers and foreign investors have transformed rural houses into bed and breakfast (BNB) and agritainment (A), which has also promoted the development of tourism. Zhonganqiao is located in Zhenze Town, the hometown of silk in China. The favorable natural conditions of Jiangnan (south of the lower reaches of the Yangtze River) provide advantageous bases for agricultural production. In the past, villagers were mainly occupied in agricultural work, consisting primarily of farming and mulberry planting. After the reform and opening up, influenced by the "Sunan mode", the attractiveness of agriculture to local labor forces has been in decline. During rural industrialization, a group of TVEs specialized in textile processing were spontaneously formed in the development of local competitive textile industries. These enterprises absorb labor forces from neighboring towns and villages, and are concentrated mainly along National Highway 318 in the southeastern part of the village. Jishan neighbors Huaqiao Town, which is located 
on the Jiangsu-Shanghai border. In recent years, Jishan has accepted a large number of functional spillovers from urban areas, forming a development mode dominated by modern service industries. The local government promoted rural urbanization through top-down administrative forces and dismantled most of the randomly scattered rural residential areas. Villagers were settled into unified residential communities (R). At the same time, to meet the needs of industrial development, logistics parks $(\mathrm{L})$, trading centers $(\mathrm{T})$, hotels $(\mathrm{H})$, and vocational schools $(\mathrm{S})$ were built. The reconstructed rural space is almost identical to that of towns and cities.
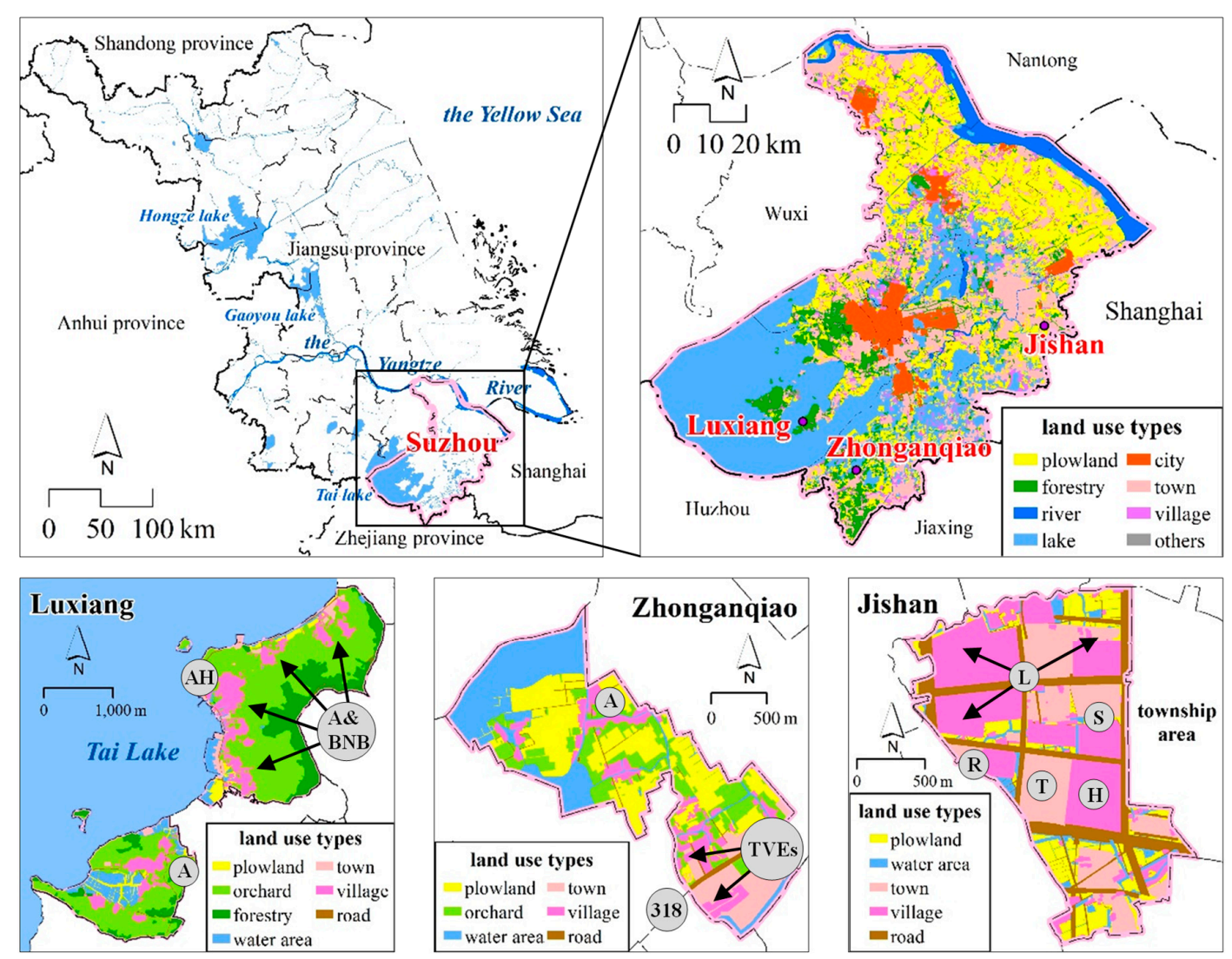

Figure 1. Study case areas: Three villages in Suzhou.

\subsection{Data}

\subsubsection{Land Use Data}

The land use data in this study are collected from the result of the second national land survey in China, an annual change database possessed by administrative institution for regulating and decision-making purpose. According to the National Standard of the People's Republic of China "current land use classification" (GB/T21010-2007) and the characteristics of land use in three villages, types of land use are divided the into plowland, orchard, forestry, water area, town, village, and road. Further, based on the classification of land use at village level, ecological, agricultural, and construction spaces are also divided.

According to the results of land survey in 2017 (Table 1), area of Luxiang, Zhonganqiao and Jishan is $7.1542 \mathrm{~km}^{2}, 3.5112 \mathrm{~km}^{2}$, and $2.9212 \mathrm{~km}^{2}$, respectively. Table 1 shows that the major spatial structure in Luxiang and Zhonganqiao; both villages far away from urban areas and are ecological and agricultural spaces, the combined ratio of both spaces is up to $83.13 \%$ and $74.95 \%$, respectively. Things are quite different in Jishan, a village located on the outskirts of urban areas, rural area is mainly dominated by construction space, and the combined ratio of town, village, and road is as high as $80.55 \%$. 
Table 1. Spatial structure of the three villages in 2017.

\begin{tabular}{|c|c|c|c|c|c|c|c|}
\hline \multirow{2}{*}{\multicolumn{2}{|c|}{ Rural Space }} & \multicolumn{2}{|c|}{ Luxiang } & \multicolumn{2}{|c|}{ Zhonganqiao } & \multicolumn{2}{|c|}{ Jishan } \\
\hline & & $\begin{array}{c}\text { Area } \\
\left(\mathrm{km}^{2}\right)\end{array}$ & $\begin{array}{c}\text { Ratio } \\
(\%)\end{array}$ & $\begin{array}{c}\text { Area } \\
\left(\mathrm{km}^{2}\right)\end{array}$ & $\begin{array}{c}\text { Ratio } \\
(\%)\end{array}$ & $\begin{array}{c}\text { Area } \\
\left(\mathrm{km}^{2}\right)\end{array}$ & $\begin{array}{c}\text { Ratio } \\
(\%)\end{array}$ \\
\hline \multirow{3}{*}{$\begin{array}{l}\text { ecological } \\
\text { space }\end{array}$} & subtotal & 1.7572 & 24.56 & 0.9555 & 27.21 & 0.1877 & 6.42 \\
\hline & forestry & 1.1629 & 16.25 & 0.0000 & 0.00 & 0.0000 & 0.00 \\
\hline & water area & 0.5943 & 8.31 & 0.9555 & 27.21 & 0.1877 & 6.42 \\
\hline \multirow{3}{*}{$\begin{array}{l}\text { agricultural } \\
\text { space }\end{array}$} & subtotal & 4.1897 & 58.56 & 1.6762 & 47.74 & 0.3806 & 13.03 \\
\hline & plowland & 0.2457 & 3.43 & 1.0374 & 29.55 & 0.3806 & 13.03 \\
\hline & orchard & 3.9440 & 55.13 & 0.6387 & 18.19 & 0.0000 & 0.00 \\
\hline \multirow{4}{*}{$\begin{array}{l}\text { construction } \\
\text { space }\end{array}$} & subtotal & 1.2072 & 16.87 & 0.8796 & 25.05 & 2.3529 & 80.55 \\
\hline & town & 0.1909 & 2.67 & 0.4083 & 11.63 & 0.6994 & 23.94 \\
\hline & village & 0.9141 & 12.78 & 0.3934 & 11.21 & 1.0808 & 37.00 \\
\hline & road & 0.1022 & 1.43 & 0.0778 & 2.22 & 0.5727 & 19.61 \\
\hline \multicolumn{2}{|c|}{ total } & 7.1542 & 100.00 & 3.5112 & 100.00 & 2.9212 & 100.00 \\
\hline
\end{tabular}

\subsubsection{Tencent LBS Data}

The real-time Tencent user quantity (RTUQ) data is a type of LBS data provided by Tencent Company; it contains real-time numbers of mobile device users who use Tencent applications, such as Tencent Mobile App QQ, WeChat, and other mobile applications that provide location-based service using GPS devices with a spatial accuracy level of $\sim 10 \mathrm{~m}$ [24,52]. Unlike old-fashioned mobile phone position data with a spatial resolution of $\sim 100 \mathrm{~m}$ to $300 \mathrm{~m}$, due to the service coverage of cell towers defined by Voronoi tessellations according to related studies $[53,54]$, the RTUQ data has higher accuracy to record and collect user's position in a relatively small-scale area. Besides, the RTUQ data is a kind of Volunteered Geographic Information (VGI) as it only obtains and records user's location information when the LBS App is used. To be emphasized, use of the RTUQ data is not subject to further scrutiny caused by user privacy issues because it only show the count of users in certain area without any personal private information. According to "Tencent announces 2018 Fourth Quarter and Annual Results", Tencent App Weixin and QQ, represent the largest social communities in China in terms of combined Monthly Active Users (MAU). The combined MAU of Weixin and WeChat increased to approximately 1098 million by the end of 2018, and the overall MAU of QQ increased to 807 million. The most important thing is that, the RTUQ data is available in both urban and rural areas. So basically, the RTUQ data fits the need to be validly and reliably used to analyze the spatiotemporal variation of human mobilities represented by real-time Tencent users (RTU), as well as to count the total quantity even in small-scale areas like villages.

We request one week hourly interval RTUQ data from 31 December 2018 to 6 January 2019 (Figure 2), considering that the period contains holidays (31 December 2018 to 1 January 2019), weekdays (2 January 2019 to 4 January 2019), and weekends (5 January 2019 to 6 January 2019). The results are presented as ArcGIS point shapefiles with location attributes and quantity of Tencent App users (Table 2); more than 250,000 records were retained after data cleaning work. 


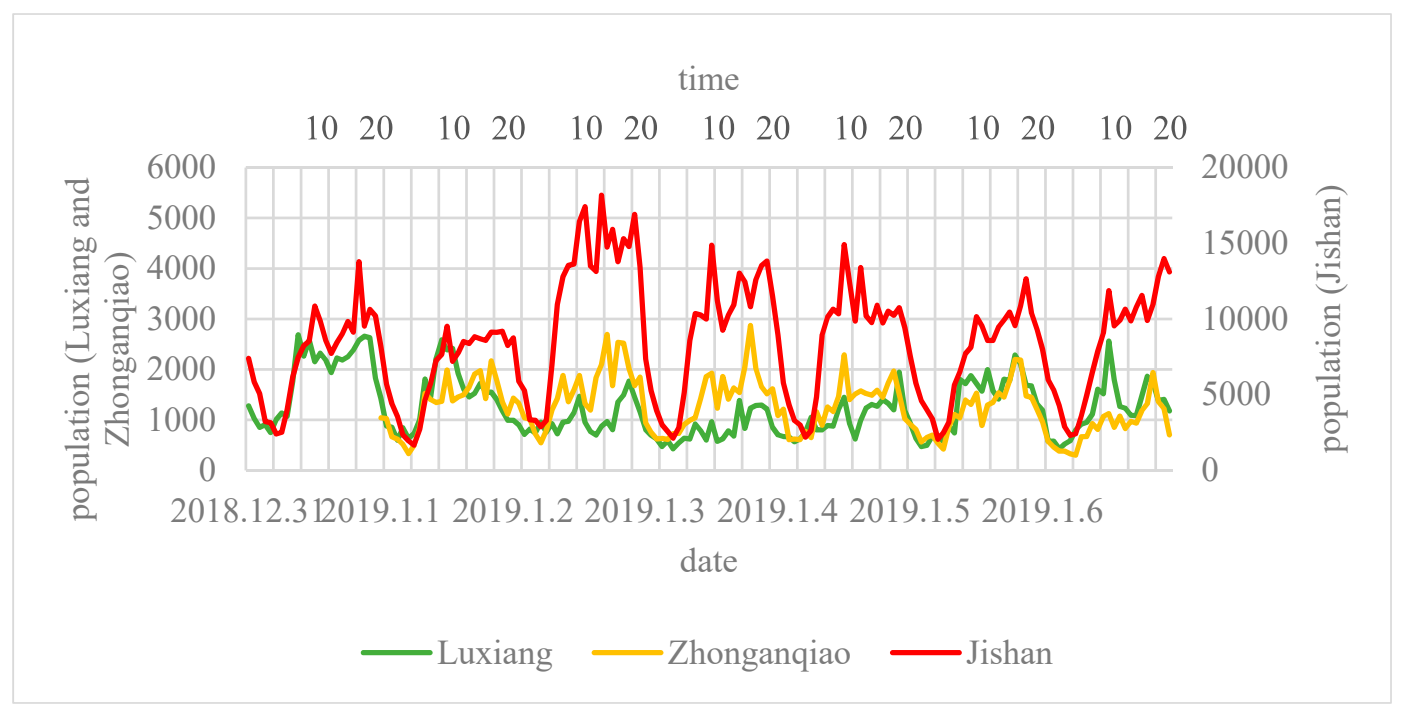

Figure 2. One week hourly real-time Tencent user quantity (RTUQ) data in study case areas.

Table 2. A detailed format of the RTUQ data.

\begin{tabular}{|c|c|c|c|}
\hline Name & Description & Type & Remark \\
\hline id & serial number of area requested after approval & string & - \\
\hline begin & time for beginning & integer & $\begin{array}{l}\text { accurate to the second, begin and end } \\
\text { both hourly, time span less than } 2 \text { days }\end{array}$ \\
\hline $\begin{array}{l}\text { end } \\
\text { interval }\end{array}$ & $\begin{array}{l}\text { time for ending } \\
\text { granularity of time interval }\end{array}$ & integer & $\begin{array}{l}\text { the same as above } \\
\text { choose from } 5,10,30 \text {, or } 60 \mathrm{~min}\end{array}$ \\
\hline data & $\begin{array}{l}\text { elements including time (string) and users } \\
\text { quantity (integer) }\end{array}$ & array & $\begin{array}{l}\text { for example: \{“time": “31 December } \\
2018 \text { 12:05:00", “quantity": 18,746\} }\end{array}$ \\
\hline
\end{tabular}

\subsection{Function Index Built}

As Merriman suggested, recent work consider mobility as a process "actively shaping or producing multiple, dynamic spaces" [55], the arrival of ex-urban residents, the departure of young people to cities, the return of out-migrants, and the holiday or seasonal flows of urban tourists to and through these places, indicate that rural places remain in a continual state of flux, always being remade and never completed. Human mobilities has long represented a significant research theme within rural studies, both in terms of the spatial analysis of population movements between rural and urban places [56-58] and the reciprocal relationship between mobilities and the dynamics of rural space [59-61]. In the process of industrialization, urbanization, and modernization in Suzhou, rural space and its functions have undergone transformation and differentiation. The functions of rural space developed from the sole residential function of "start farming at sunrise and rest at sunset", in the period of small-scale peasant economy, to the combined residential and employment functions of "leaving farmland without leaving villages, entering factories without entering cities" during the "Sunan mode" period. The development then reaches a stage of urban-rural integration with the holiday consumption function of "pastoral scene is more attractive to urban dwellers". Constant changes of the purposes for behavior and human activity modes mirror the multifunctional differentiation of rural spaces, which provides the basis for application of the RTUQ data to measure multifunctionality of rural space, driven by spatiotemporal variation of human mobilities.

In this study, three functional indices of residence, employment, and consumption in rural spaces are built. The purposes of these indices are to quantitatively compare the differences in the functions of residence, employment, and consumption between different rural spaces, as well as changes in functional indices during different periods (weekdays, weekends, and holidays) within the same rural space. Index of residential function reflects the nature of starting work at sunrise and resting 
at sunset by calculating the ratio between daytime and night-time population size in a rural space. In general, the population size of rural space with residential function should be larger at night than during the day. Index of employment function highlights the increment of population in the daytime on weekdays relative to that on weekends and holidays. Rural spaces with an employment function usually also have certain residential function, thereby playing host to a mixture of employment and residential functions. Index of consumption function reflects the increment of population on weekends and holidays compared to weekdays. With BNB becoming popular in recent years, measurements of the holiday economy should consider not only those tourists who visit during the day but also those who stay overnight. Therefore, population increment in the daytime and night-time on weekends and holidays should both be considered. Equations built in this study for indices of residential, employment and consumption functions are as follows.

$$
\begin{gathered}
R_{i}=\frac{Q e_{i}}{Q d_{i}} \\
E_{i}=\frac{Q d_{i}}{\frac{1}{m} \sum_{a=1}^{m} Q d_{a}} \times \frac{Q d_{i}}{\frac{1}{n} \sum_{b=1}^{n} Q d_{b}} \\
C_{i}=\frac{Q d_{i}}{\frac{1}{k} \sum_{c=1}^{k} Q d_{c}} \times \frac{Q e_{i}}{\frac{1}{k} \sum_{c=1}^{k} Q e_{c}}
\end{gathered}
$$

where,

- $R_{i}$ is the index of residential function.

- $Q d_{i}$ and $Q e_{i}$, respectively, are the RTUQ in day and evening. In this study, $i=1,2 \ldots 7$, dates from 31 December 2018 to 6 January 2019.

- $E_{i}$ is the index of employment function.

- $C_{i}$ is the index of consumption function.

- $m, n$, and $k$, respectively, is the number of holidays, weekends and weekdays. In this study, $a=1$ and 2, and dates from 31 December 2018 to 1 January 2019; $b=1$ and 2, and dates from 5 to 6 January 2019; and $c=1,2$, and 3, and dates from 2 to 4 January 2019.

\section{Results}

\subsection{Perceiving Spatiotemporal Patterns of Human Mobilities}

Quantity and distribution of RTU in different epochs could intuitively reflect the possession of multiple resources by lives of the rural, thus to explore the change of man-land relationship in rural space, as well as functions and values. This study choose different epochs at 10:00 a.m. and 20:00 p.m. (relatively peak RTUQ in daytime and night-time, see Figure 2) on holidays, weekdays, and weekends in three case areas, to compare the change of RTU in rural spaces (Chosen date of holiday, weekday and weekend for Luxiang is 31 December 2018, 3 January 2019 and 5 January 2019, respectively. For Zhonganqiao is 1, 3, and 6 January 2019, and 1, 2, and 6 January for Jishan). Table 3 shows RTUQ in different epochs, obviously, there is a net inflow of population on holiday and weekend in Luxiang, and a net outflow in Zhonganqiao and Jishan. Further, RTUQ is divided into four classes $(<10,10-50$, $50-100$, and $>100$ ), for the purpose of observing distribution variation of RTU with different quantities on holidays, weekdays, and weekends. 
Table 3. RTUQ of three villages in different epochs.

\begin{tabular}{ccccccc}
\hline \multirow{2}{*}{ Village } & \multicolumn{2}{c}{ Holiday } & \multicolumn{2}{c}{ Weekday } & \multicolumn{2}{c}{ Weekend } \\
\cline { 2 - 7 } & $\mathbf{1 0 : 0 0}$ & $\mathbf{2 0 : 0 0}$ & $\mathbf{1 0 : 0 0}$ & $\mathbf{2 0 : 0 0}$ & $\mathbf{1 0 : 0 0}$ & $\mathbf{2 0 : 0 0}$ \\
\hline Luxiang & 2263 & 2578 & 785 & 1285 & 1719 & 2102 \\
Zhonganqiao & 1345 & 2169 & 1416 & 2016 & 812 & 1937 \\
Jishan & 7254 & 9134 & 13,534 & 15,298 & 7859 & 10,962 \\
\hline
\end{tabular}

\subsubsection{Prominent Holiday Economy in Luxiang}

Luxiang faces Tai Lake and backs up to East Mountain. The road transportation on the eastern side of Tai lake is the primary way for villagers to travel. On weekdays, RTU is mainly local villagers, scattered throughout various settlements. Daytime and night-time RTU are 785 and 1285, respectively. On weekend and holiday, the inflow of a large number of tourists leads to a significant expansion of RTU. Especially on holiday, the daytime and night-time RTU increases to 2263 and 2578, respectively. Spatially, tourists are mainly concentrated in the northern part of the village on weekend and holiday (Figure 3). This concentration occurs not only because Luxiang ancient hamlet, a historical and cultural settlement, is located there, but also because many BNBs and agritainment have been built along the road in recent years to attract tourists. The southern part of the village is still characterized by featured agriculture. It is worth noting that in the night-time on weekend and holiday, a large number of tourists remain gathered in the northern part of the village. Multiple areas with RTUQ class larger than 50 appear, which indicates that the development of BNB plays a role in extending tourists' stay duration. Attracting tourists staying overnight has become an important way for Luxiang to develop holiday economy.

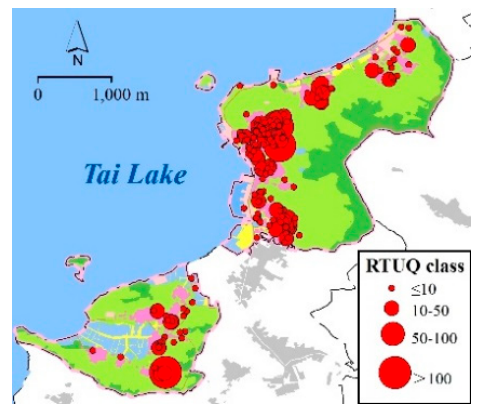

(a)

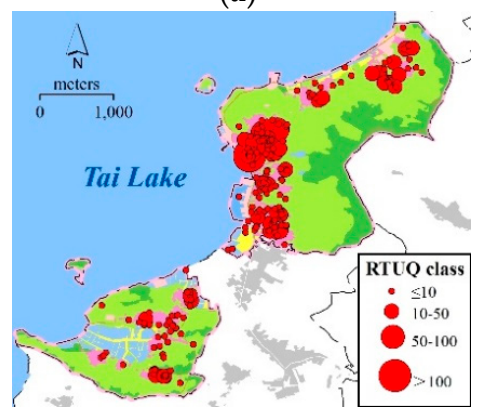

(b)

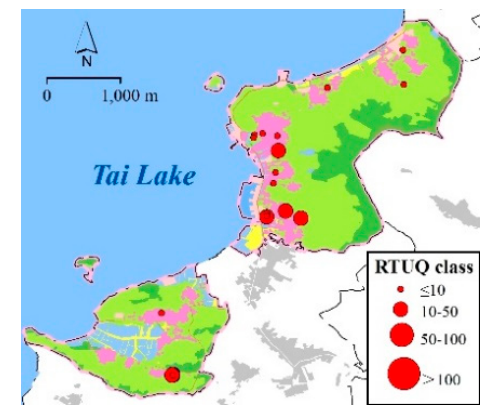

(c)

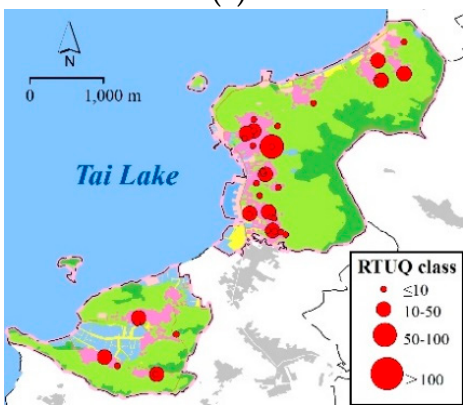

(d)

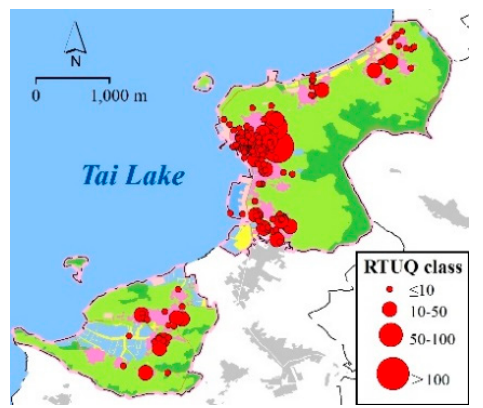

(e)

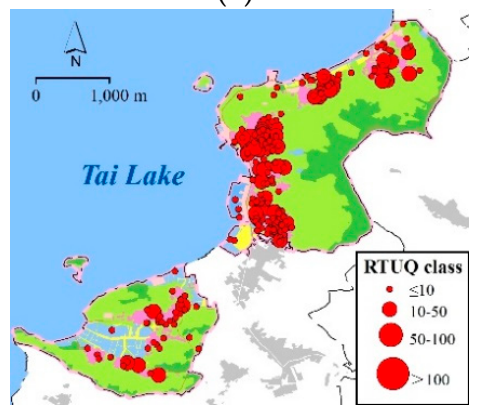

(f)

Figure 3. Spatiotemporal distribution of RTU in Luxiang. (a) 10:00 a.m., holiday. (c) 10:00 a.m., weekday. (e) 10:00 a.m., weekend. (b) 20:00 p.m., holiday. (d) 20:00 p.m., weekday. (f) 20:00 p.m., weekend.

\subsubsection{Transport-Oriented Development in Zhonganqiao}

Zhonganqiao is a rural space with an obvious transition of regional landscapes. The northwestern part of the area is dominated by water area, the middle by agricultural land, and the southeastern part by TVEs and rural settlements adjacent to National Highway 318. During both working and 
non-working days, RTU is mainly concentrated near the National Highway 318 in this region (Figure 4). This concentration shows that the highway, as the main transportation pathway, has aggregated most of the functions of production and living in rural space. The development of Zhonganqiao has shown obvious unidirection in spatial distribution. Note that the distribution of RTU in the southeastern part of the village on weekday is scattered and that the RTUQ class of almost all of the areas is less than 10, reflecting that TVEs of the Sunan mode are characterized by small scale and scattered distribution. At night, RTU shows concentrated distribution, and the number of areas with RTUQ class larger than 10 doubles compared to that during the day. This increase suggests that villagers still mainly reside together. On holidays, RTU also increases in some areas of the northwestern and central parts of the village, which may be because residents in the surrounding areas engage in recreational activities such as fishing.

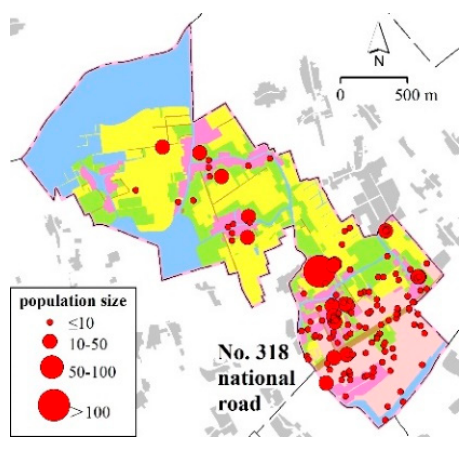

(a)

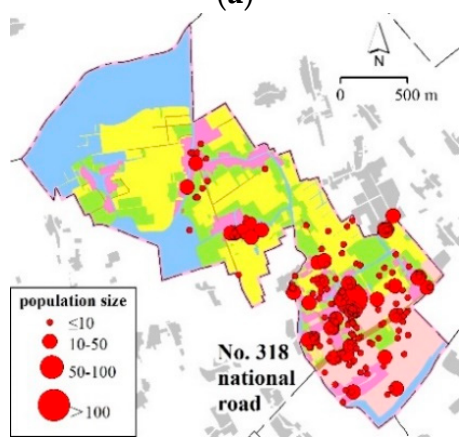

(b)

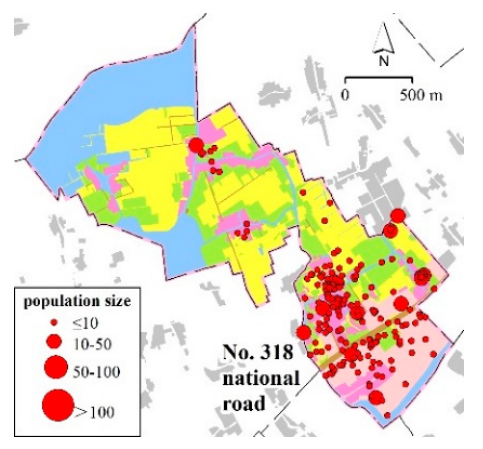

(c)

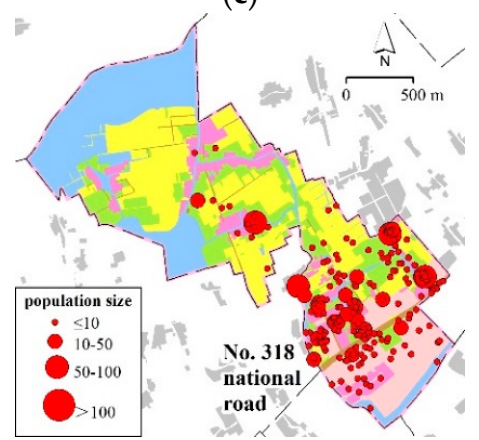

(d)

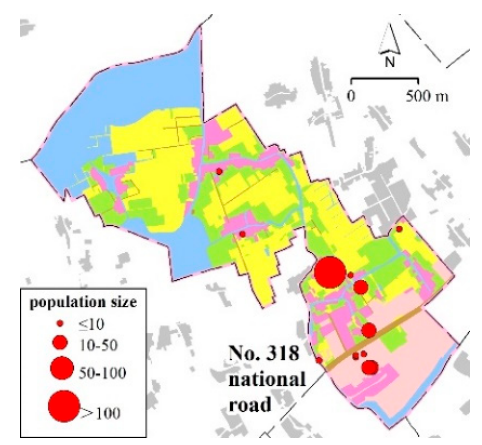

(e)

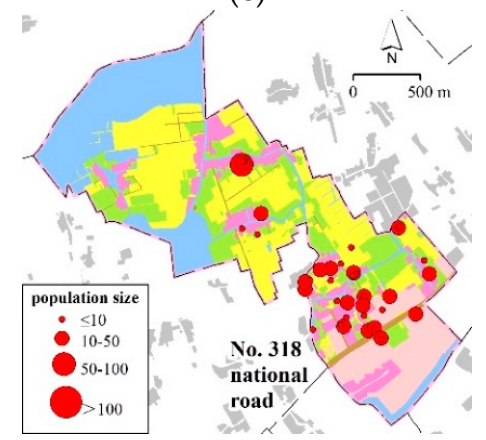

(f)

Figure 4. Spatiotemporal distribution of RTU in Zhonganqiao. (a) 10:00 a.m., holiday. (c) 10:00 a.m., weekday. (e) 10:00 a.m., weekend. (b) 20:00 p.m., holiday. (d) 20:00 p.m., weekday. (f) 20:00 p.m., weekend.

\subsubsection{Seasonal Flow Out in Jishan}

The most obvious changes of RTU in Jishan are reflected by rural "hollowing" on holidays (Figure 5). On weekday, RTU is concentrated mainly in logistics parks, vocational schools, and residential communities. At night, RTU density in logistics parks decreases. Vocational schools are managed as boarding schools, and their RTU changes are not obvious between daytime and night-time. RTU in residential communities increases significantly in the night-time. On weekend, the situation is similar to that on weekday, and major changes occur in vocational schools. Students have their days off and return to school at night, and therefore RTU in vocational schools increases significantly at night. Changes are the most obvious on holiday. The density of RTU in logistics parks, vocational schools, and residential communities drops significantly, showing a clear "hollowing" phenomenon. This phenomenon indicates that on the one hand, Jishan has developed modern service industries and that most of the employees are migrant workers, they spend their holidays returning home in other places. On the other hand, the migrant workers can make a round trip within the three-day New Year's holiday, indicating that most of them come from surrounding villages and towns. 


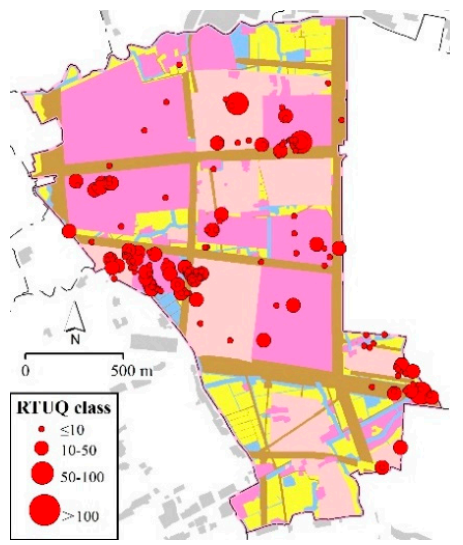

(a)

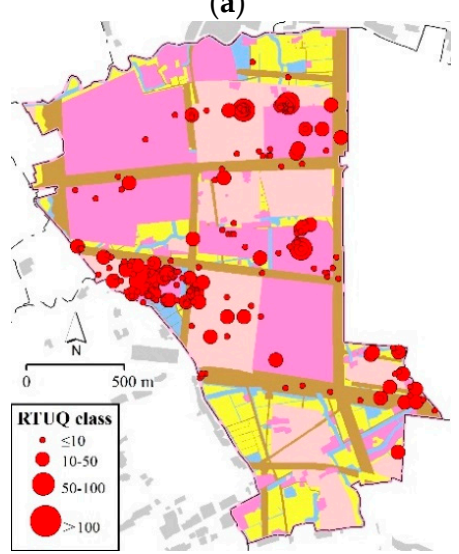

(b)

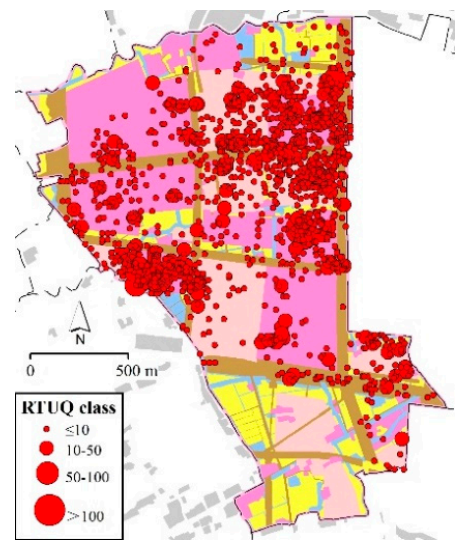

(c)

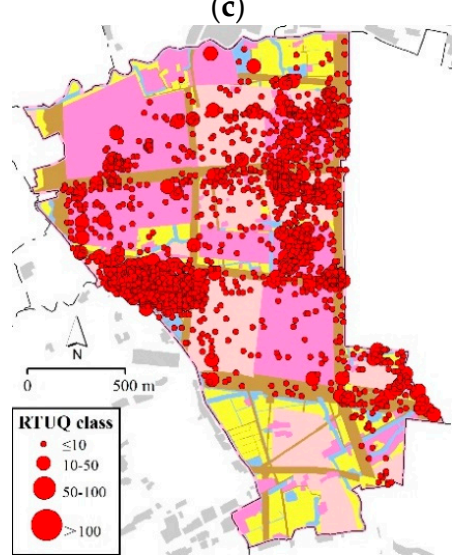

(d)

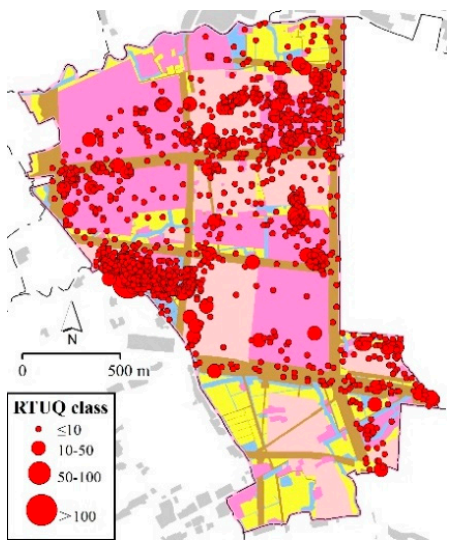

(e)

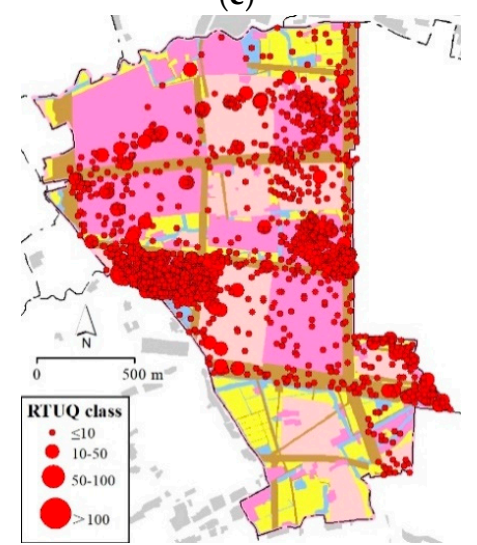

(f)

Figure 5. Spatiotemporal distribution of RTU in Jishan. (a) 10:00 a.m., holiday. (c) 10:00 a.m., weekday. (e) 10:00 a.m., weekend. (b) 20:00 p.m., holiday. (d) 20:00 p.m., weekday. (f) 20:00 p.m., weekend.

\subsection{Measuring Multifunctionality Based on Function Index}

Different characteristics of spatial distribution and quantity classes of RTU on holiday, weekday, and weekend in Luxiang, Zhonganqiao, and Jishan highlight the dynamic variation of function in rural space. And hence, quantitative measurement of each function and its change over periods in three case areas is carried out based on the function index of rural space proposed in this study.

\subsubsection{Calculate RTUQ of Day and Evening}

Change of hourly RTUQ in 24-h on holiday, weekday, and weekend in Luxiang, Zhonganqiao, and Jishan is shown in Figure 6. Although hourly RTUQ data fluctuates, the hours of peak values have their own regularity. For example, peak value in daytime and night-time in Luxiang appears at 9:00 a.m. (2687) and 21 p.m. (2655) on holiday, at 9:00 a.m. (1801) and 19 p.m. (2284) on weekend, at 12:00 a.m. (964) and 21 p.m. (1294) on weekday. Note that peak values mainly focus on 9:00 a.m. to 12:00 a.m. in daytime and 19:00 p.m. to 22:00 p.m. in night-time; the same as in Zhonganqiao and Jishan. Thus, average value from 9:00 a.m. to 12:00 a.m. in daytime and 19:00 p.m. to 22:00 p.m. in night-time ( $4 \mathrm{~h}$ each periods) is used to calculate $Q d_{i}$ and $Q e_{i}$, equations are as follows. Further, Table 4 shows the results of $Q d$ and Qe of Luxiang, Zhonganqiao, and Jishan dates from 31 December 2018 to 6 January 2019.

$$
Q d_{i}=\frac{1}{t} \sum_{t_{1}}^{t_{1}+t} Q d_{i j}
$$




$$
Q e_{i}=\frac{1}{t} \sum_{t_{2}}^{t_{2}+t} Q e_{i j}
$$

where,

- $\quad Q d_{i j}$ and $Q e_{i j}$, respectively, are the hourly RTUQ data of day and evening.

- $\quad t_{1}$ and $t_{2}$, respectively, are the hour of day and evening; $t$ is the number of hours; $j=0,1 \ldots t_{1} \ldots$ $t_{2} \ldots$ 23. In this study, $t_{1}=9, t_{2}=19, t=4$.

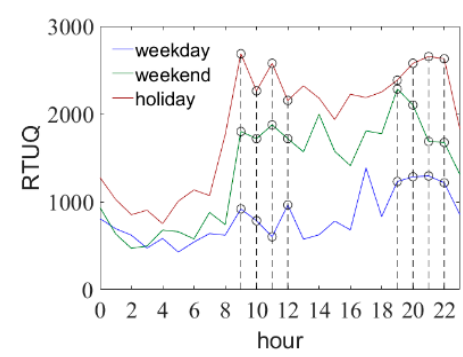

(a)

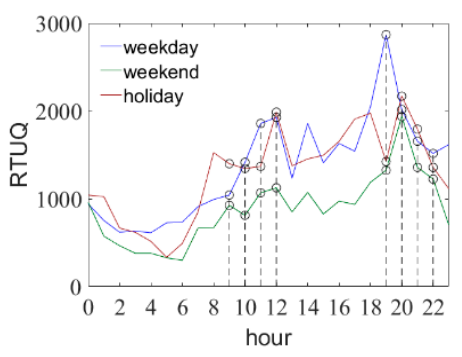

(b)

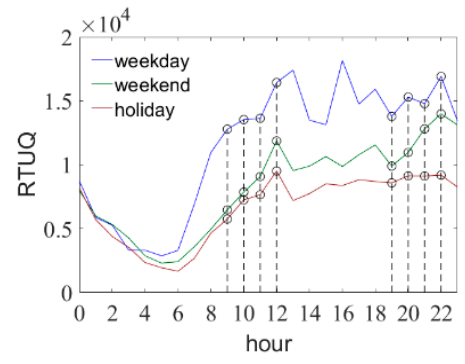

(c)

Figure 6. RTUQ change in 24-h on weekday, weekend, and holiday. (a) Luxiang. (b) Zhonganqiao. (c) Jishan.

Table 4. Results of $Q d$ and $Q e$ of the three villages during the research period.

\begin{tabular}{cccccccc}
\hline \multirow{2}{*}{ Period } & \multirow{2}{*}{ Date } & \multicolumn{2}{c}{ Luxiang } & \multicolumn{2}{c}{ Zhonganqiao } & \multicolumn{2}{c}{ Jishan } \\
\cline { 2 - 7 } & & $Q d$ & $Q e$ & $Q d$ & $Q e$ & $Q d$ & $Q e$ \\
\hline \multirow{2}{*}{ vacation } & 31 December 2018 & 2421 & 2562 & -1 & - & 8772 & 10,769 \\
& 1 January 2019 & 2162 & 1423 & 1525 & 1686 & 7543 & 9007 \\
\hline \multirow{3}{*}{ workday } & 2 January 2019 & 1136 & 1517 & 1678 & 2188 & 14,097 & 15,193 \\
& 3 January 2019 & 817 & 1257 & 1561 & 2014 & 11,372 & 12,687 \\
& 4 January 2019 & 1105 & 1468 & 1545 & 1663 & 11,505 & 10,303 \\
\hline \multirow{2}{*}{ weekend } & 5 January 2019 & 1779 & 1937 & 1317 & 1827 & 8120 & 10,864 \\
& 6 January 2019 & 1700 & 1599 & 983 & 1461 & 8818 & 11,914 \\
\hline
\end{tabular}

${ }^{1}$ The RTUQ data of Zhonganqiao in 31 December 2018 is not available.

\subsubsection{Evaluate Results of Function Index}

According to Equations (1)-(3), indices of residential, employment, and consumption functions have been calculated in each day from 31 December 2018 to 6 January 2019. Table 5 shows the results of function index in Luxiang, Zhonganqiao and Jishan.

Table 5. Results of function index of the three villages.

\begin{tabular}{lcccccccccc}
\hline \multirow{2}{*}{ Period } & \multirow{2}{*}{ Date } & \multicolumn{3}{c}{ Luxiang } & \multicolumn{3}{c}{ Zhonganqiao } & \multicolumn{3}{c}{ Jishan } \\
\cline { 3 - 11 } & & $\boldsymbol{R}$ & $\boldsymbol{E}$ & $\boldsymbol{C}$ & $\boldsymbol{R}$ & $\boldsymbol{E}$ & $\boldsymbol{C}$ & $\boldsymbol{R}$ & $\boldsymbol{E}$ & $\boldsymbol{C}$ \\
\hline \multirow{2}{*}{ holidays } & 31 December 2018 & 1.0583 & 1.4699 & 4.3025 & - & - & - & 1.2277 & 1.1137 & 0.6022 \\
& 1 January 2019 & 0.6583 & 1.1729 & 2.1358 & 1.1053 & 1.3260 & 0.8246 & 1.1940 & 0.8236 & 0.4331 \\
\hline \multirow{3}{*}{ weekdays } & 2 January 2019 & 1.3351 & 0.3237 & 1.1954 & 1.3042 & 1.6050 & 1.1777 & 1.0778 & 2.8764 & 1.3654 \\
& 3 January 2019 & 1.5379 & 0.1675 & 0.7125 & 1.2905 & 1.3891 & 1.0086 & 1.1156 & 1.8717 & 0.9197 \\
& 4 January 2019 & 1.3286 & 0.3063 & 1.1257 & 1.0764 & 1.3605 & 0.8239 & 0.8955 & 1.9159 & 0.7557 \\
\hline \multirow{2}{*}{ weekends } & 5 January 2019 & 1.0891 & 0.7938 & 2.3911 & 1.3870 & 0.9896 & 0.7723 & 1.3379 & 0.9544 & 0.5624 \\
& 6 January 2019 & 0.9407 & 0.7253 & 1.8871 & 1.4867 & 0.5506 & 0.4606 & 1.3511 & 1.1255 & 0.6698 \\
\hline
\end{tabular}


In Luxiang, the index of residential function varies between 0.6583 and 1.5379, with the highest value on 3 January 2019 (weekday) and the lowest on 1 January 2019 (holiday). The residential function on weekdays is more apparent, but due to the daytime increase in the number of tourists on weekends and holidays, $Q d$ is high, whereas $Q e$ is low, showing a "reversed" situation of $Q d$ and $Q e$. Index of employment function varies between 0.1675 and 1.4699, with the highest value on 31 December 2018 (holiday), and the lowest on 3 January 2019 (weekday). The index reflects the proportional relationship between $Q d$ on weekdays and $Q d$ on weekends and holidays. The results show that the employment function of Luxiang on weekdays is not obvious. Index of consumption function varies between 0.7125 and 4.3025, with the highest value on 31 December 2018 (holiday), and the lowest on 3 January 2019 (weekday). The index represents the proportional relationship between $Q d$ and $Q e$ on weekends and holidays and on weekdays. The highest value (4.305) appeared on 31 December 2018, which was the second day of the New Year's holiday. Many tourists not only visited Luxiang during the day, but also chose to stay in the local BNB at night. Qd and Qe were as high as 2421 and 2562, respectively, reaching the highest values within a week. Likewise, the second highest value appeared on 5 January 2019. This day was a Saturday, and many tourists also chose to stay in Luxiang that night. Qe reached 1937, which was the second highest value in a week. This result shows that the consumption function index contains changes in $Q d$ and $Q e$ and can be further used to analyze the impact of tourists staying overnight on the holiday economy.

In Zhonganqiao, index of residential function varies between 1.0764 and 1.4867, with the highest value on 6 January 2019 (weekend), and the lowest on 4 January 2019 (weekday). Though Friday has the lowest value, $Q d$ on that day is almost the same with the previous two weekdays, which is 1678,1561 , and 1545 , respectively. What really changes is the apparent decrease of Qe, drops to 1663 from 2188 and 2014 of the two previous weekdays. These results show that part of the labor workers left Zhonganqiao after work on Friday and returned to Zhonganqiao before going to work on Monday. It is very likely that this part of the labor force comes from surrounding villages and towns. On weekdays, they work in TVEs in Zhonganqiao and return to their respective villages on weekends. Index of employment function varies between 0.5506 and 1.6050, with the highest value on 2 January 2019 (weekday), and the lowest on 6 January 2019 (weekend). Moreover, these two days also have the highest (1678) and lowest (983) value of $Q d$ during the whole research period. The difference between the lowest and highest values of $Q d$ accounts for $41.43 \%$ of the highest value $O d$, indicative of the proportion of migrant laborers in TVEs, to some extent. At the same time, the employment function index on holidays also reaches 1.3260, and the reduction of $Q d$ on holidays is not as obvious as on weekends, indicating that there is some inflow of population on holidays. Index of consumption function varies between 0.4606 and 1.1777 , both the weekends and holidays has a low value, which means no obvious consumption function in Zhonganqiao.

In Jishan, index of residential function varies between 0.8955 and 1.3511, with the highest value on 6 January 2019 (weekend), and the lowest on 4 January 2019 (weekday), basically identical to those of Zhonganqiao, indicating the influence of migrant laborers on residential function. Index of employment function varies between 0.8236 and 2.8764, the highest values appear on the three weekdays, 2.8764, 1.8717, and 1.9159, respectively, much higher than those on the same weekdays in Zhonganqiao (1.6050, 1.3891, and 1.3605, respectively), reflecting a stronger employment function in Jishan. Moreover, though area of construction space in Jishan $\left(2.3529 \mathrm{~km}^{2}\right)$ is only 2.67 times than in Zhonganqiao $\left(0.8796 \mathrm{~km}^{2}\right)$, the summation of $Q d$ on the three weekdays is 7.73 times, while summation of Qe is 6.51 times. Obviously, the development mode of industrial parks in Jishan has greater scale effect than conventional Sunan model in Zhonganqiao. Index of consumption function varies between 0.4331 and 1.3654, low values both on weekend and holiday, which is the same as in Zhonganqiao.

In summary, the highest values of the residential, employment, and consumption function indices for the three case areas on weekdays, weekends, and holidays are shown in Figure 7. The consumption function index of Luxiang is the highest on weekends and holidays, reaching 2.3911 and 4.3025, respectively. This result indicates that Luxiang has accomplished the transition to 
holiday consumption-oriented rural space. A tourist service-based holiday economy plays an important role in promoting the village's multifunctional development. Changes of the functional indices of Zhonganqiao in the three different periods are not obvious. Relatively speaking, the employment function index on weekdays increases slightly, reaching 1.6050, reflecting the limited effects of TVEs in promoting rural industrialization. Changes of the functional indices of Jishan on weekends and holidays are basically identical to those of Zhonganqiao. However, the employment function index of Jishan on weekdays is as high as 2.8764, reflecting the effects of scale economies in the economic development mode of industrial parks. To distinguish the different stage in rural industrialization in China, some scholars even named the mode in Jishan as "beyond the Sunan model" [62,63].

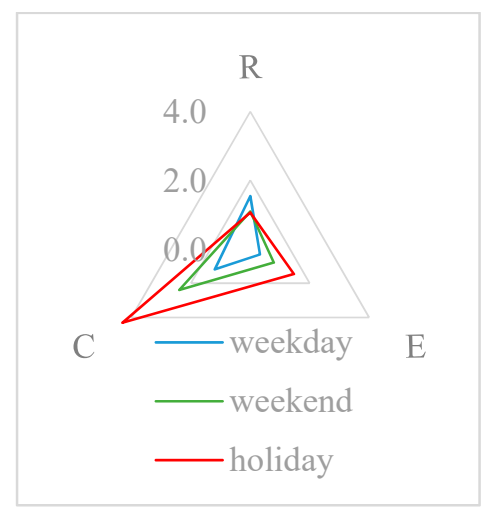

(a)

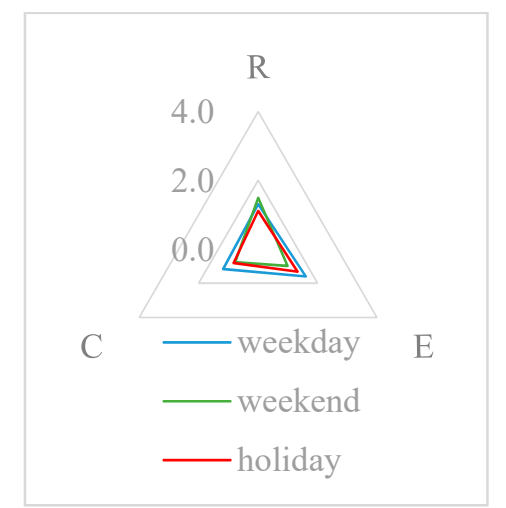

(b)

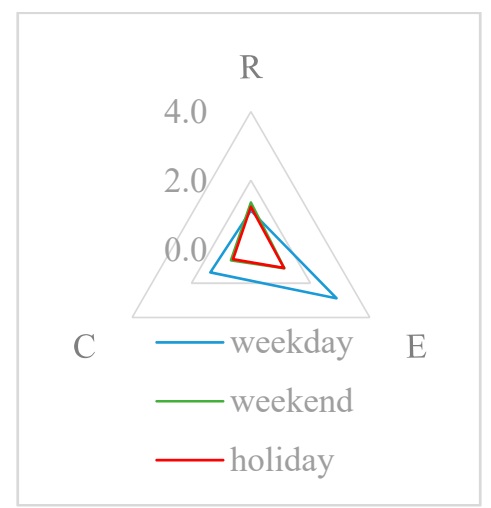

(c)

Figure 7. Function index of three villages in different periods. (a) Luxiang. (b) Zhonganqiao. (c) Jishan.

\section{Discussion}

\subsection{Methodological Contributions}

Though the reciprocal relationship between mobilities and the dynamics of rural space has long been represented as a significant research theme within rural studies, most of the previous studies involving human activities in rural places adopt self-report or site observation data via social surveys, which is both time-consuming and laborious. For example, Milbourne and Kitchen examined the mobilities within the lives of rural residents in Wales through face-to-face interviews and questionnaires over a period of 18 months [59]; some interviewees were even requested to complete a written diary covering their activities in a particular week. Tu carried out an empirical study on the process of rural restructuring in Huangshandian village, a suburb of Beijing, by inquiring into and recording information from the village cadres and local elders who have stayed in the village for a long time [64]. It is true that more details could be obtained via field investigation, but this study aims to explore multifunctionality of rural space with data generated from human mobilities, quantity and distribution of moving observables in rural space matters and foremost. Obviously, the technology of big data qualifies better than traditional method of social survey, but still less attention has been found in rural geography using the emerging big data.

This study provides an original method for measuring and distinguishing multifunctionality of rural space on holidays, weekdays and weekends at the village level. Based on over 250,000 records of hourly RTUQ data in one-week research period, spatiotemporal variation of human activities in three differentiated villages has been perceived. Further, multifunctionality of residence, employment and consumption are quickly and accurately measured following the original equations of function index. The results indicate that the intensity of function varies according to the RTUQ change inside the village at specified epoch, which makes the proposed method suitable for identifying and comparing multifunctionality of rural space in various times and places. 


\subsection{Implications for Transitional Pathways of Decision-Making}

As Rigg highlighted, rural areas in transition economies such as China have increasingly changed from production to consumption-oriented locations, driven by processes such as industrialization, deagrarianization, and counterurbanization [65]. This has often been accompanied by agricultural depopulation, outmigration, increasing non-farm employment, declining agricultural incomes, and associated social and psychological changes [8]. Multidimensional and hybrid development pathways in which questions about the "right" and "wrong" development trajectories are increasingly difficult to answer, these disturbances pose enormous challenges about how to tackle environmental and social changes, who should be in charge of making key decisions about possibly altering current "unsustainable" lifestyles, and what institutional and policy-related mechanisms should be used to influence decision-making processes [66]. By analyzing distribution variation of RTU with different quantities on holidays, weekdays and weekends, this study has verified that spatiotemporal patterns of human mobilities is an important driving force to formulate the multifunctionality of rural space and its developing trend, which will bring new implication for regional planning and decision-making mechanisms.

The active RTU in the northern part of Luxiang at night shows that the newly developed BNB have become an important means to attract tourists staying overnight and to promote tourism development. To further enhance the competitiveness of the holiday economy and the consumption function in rural areas, new industry such as BNB should be encouraged and regulated under intergovernmental governance. The RTU of Zhonganqiao during the day and night is mainly concentrated in the southeastern part of the village on both sides of National Highway 318. This clustering reflects the important influence of transportation on local villagers' production and living conditions, which means further infrastructure improvement is necessary to enhance the residential and employment functions of rural space undergone spatial reconstruction in similar places. Last but not the least, the significant reduction of RTU in Jishan during holiday shows that the economic mode of the industrial park dominated by administrative forces can raise the urbanization level in rural areas. However, this kind of "pseudo-urbanization" poses risks to the sustainable development of the local economy [67]; how to attract migrant workers settle down is what regional planning should take into consideration.

\subsection{Limitations}

There are two main limitations while using the RTUQ data in this study. First, the attributes of users are not available, e.g., age, gender, and others. Therefore, it is not possible to subdivide the group of observables in rural space. Second, the activity trajectory of users cannot be tracked, and therefore, Origin-Destination $(\mathrm{O}-\mathrm{D})$ of users cannot be depicted to further analyze the location and duration of users in rural space.

Otherwise, empirical analysis is also restricted to a one-week research period; some speculative results need to be verified by further work with longer and typical research periods. For example, quantity of tourists staying overnight in Luxiang and proportion of migrant laborers in Zhonganqiao and Jishan remain to be tested for their accuracy by long-term and stable observing data. However, what can be inferred from past experience is that the index of consumption function in Luxiang will continue to increase in peak tourist season in May, when seasonal fruits such as loquat and waxberry is in the market. Besides, phenomenon of rural "hollowing" in Jishan will become even more prominent in Spring Festival, the most important traditional holiday for reunion in China, which will uncover the quantity of migrant laborers in "pseudo-urbanization".

\section{Conclusions}

This study aims to explore the application of LBS data in rural geography, an original method for measuring function of residence, employment, and consumption in rural space is introduced and implemented. It is concluded that the RTUQ data is valid and reliable for perceiving dynamic variation 
of human mobilities in rural places, as well as offering new implication for transitional pathways of decision-making, considering the advantage of wide coverage, high spatial and temporal resolution. Without time-consuming and laborious field investigations, the proposed method is proved to be suitable for identifying and comparing multifunctionality of rural space in various times and places.

Taking three typical villages in Suzhou, China, as the case areas, over 250,000 records of hourly RTUQ data in one-week period from 31 December 2018 to 6 January 2019 has been obtained. On this basis, spatiotemporal variation of quantity and distribution of human activities has been perceived. The following points are noted. (1) Increment of RTU on weekends and holidays in Luxiang are mainly tourists, especially those in night-time, reflecting effects of BNB industry in promoting holiday economy, which should be encouraged and regulated in future. (2) RTU in Zhonganqiao has shown obvious unidirection in spatial distribution, reflecting the important influence of transportation on space reconstruction during the process of rural industrialization, which is necessary to further strengthen infrastructure construction. (3) RTU in Jishan is dominated by migrant workers, phenomenon of rural "hollowing" on holidays manifests that rural urbanization driven by administrative forces is a kind of "pseudo-urbanization", various measures should be carried out to attract migrant workers to settle down locally. Further, multifunctionality of residence, employment, and consumption are measured following original equations of function index. Besides, quantitative effect of function index is mainly reflects in two aspects: (1) Changes of certain function index during different periods within the same rural space, e.g., the index of consumption function in Luxiang increases to 2.3911 on weekend and 4.3025 on holiday, and manifests prominent holiday economy in rural space. (2) Comparison of certain function between different rural spaces, e.g., index of employment function differs in Zhonganqiao and Jishan on weekdays, 1.6050 and 2.8764, respectively, declares that development mode of industrial parks in Jishan has greater scale effect than conventional Sunan model in Zhonganqiao during the process of rural industrialization and urbanization.

Understanding the transition of rural multifunctionality by the data of human mobilities is great significance to reconstruct the rural space. The mobilities big data at micro-scale of rural population proves to be a useful tool to distinguish and compare perceive and measure the multifunctionality transformation of rural space. Based on the RTUQ data at village level, the paper reveals the changing process of the human mobilities, which have a profound impact on rural land use, especially affect the intensity and mode of land use. Likewise, spatiotemporal patterns of human mobilities in village level manifest that there are profound differentiation within dominant function and development trajectories considering multiple purposes of human activities. Multifunctional transition in rural area indicates that the substitution is more than a gradual linear model use to be, but as a breakthrough of traditional modernization development paradigm. With the process of rural-urban integration in contemporary China and many other developing countries in the near future, transition in rural area and its functions is predictably become much more pluralistic and complicated. Therefore, a new research agenda for combining traditional land use data with the emerging big data in exploring and understanding the contemporary rural space towards diversity and multifunctionality is urgently needed; for example, by providing scientific reference for pushing forward rural revitalization by classifying and realizing the multifunctional characteristics of the village [68], especially human geographers are now in the era of geospatial big data.

Author Contributions: Conceptualization, Y.Y.; Methodology, Y.Y. and X.Z.; Software, Y.Y.; Validation, H.L. and Y.W.; Formal analysis, X.H.; Investigation, Y.Y. and X.H.; Resources, Y.Y.; Data curation, Y.Y. and Y.W.; Writing-original draft preparation, Y.Y., H.L., and X.Z.; Writing-review and editing, Y.Y. and H.L.; Visualization, Y.Y.; Supervision, H.L.; Project administration, H.L.; Funding acquisition, H.L.

Funding: This research was funded by the National Natural Science Foundation of China, grant numbers 41571164 and 41501187.

Conflicts of Interest: The authors declare no conflicts of interest. 


\section{References}

1. McCarthy, J. Rural geography: Multifunctional rural geographies-reactionary or radical. Prog. Hum. Geogr. 2005, 29, 773-782. [CrossRef]

2. Barbieri, C.; Valdivia, C. Recreation and agroforestry: Examining new dimensions of multifunctionality in family farms. J. Rural Stud. 2010, 26, 465-473. [CrossRef]

3. Long, H.L.; Liu, Y.S. Rural restructuring in China. J. Rural Stud. 2016, 47, 387-391. [CrossRef]

4. Pribadi, D.O.; Zasada, I.; Müller, K.; Pauleit, S. Multifunctional adaption of farmers as response to urban growth in the Jabodetabek Metropolitan Area, Indonesia. J. Rural Stud. 2017, 55, 100-111. [CrossRef]

5. Oostindie, H. Unpacking Dutch multifunctional agrarian pathways as processes of peasantisation and agrarianisation. J. Rural Stud. 2018, 61, 255-264. [CrossRef]

6. Gosnell, H.; Abrams, J. Amenity migration: Diverse conceptualizations of drivers, socio-economic dimensions, and emerging challenges. GeoJournal 2011, 76, 303-322. [CrossRef]

7. Holmes, J. Cape York Peninsula, Australia: A frontier region undergoing a multifunctional transition with indigenous engagement. J. Rural Stud. 2012, 28, 252-265. [CrossRef]

8. Wilson, G.A.; Hu, Z.; Rahman, S. Community resilience in rural China: The case of Hu Village, Sichuan Province. J. Rural Stud. 2018, 60, 130-140. [CrossRef]

9. Wilson, G.A. Multifunctional Agriculture: A Transition Theory Perspective; Cromwell Press: Trowbridge, UK, 2007; pp. 179-211.

10. Marsden, T. New rural territories: Regulating the differentiated rural space. J. Rural Stud. 1998, 14, $107-117$. [CrossRef]

11. Wilson, G.A. From productivism to post-productivism and back again? Exploring the (un)changed natural and mental landscapes of European agriculture. Trans. Inst. Br. Geogr. 2001, 26, 77-102. [CrossRef]

12. Holmes, J. Impulses towards a multifunctional transition in rural Australia: Gaps in the research agenda. J. Rural Stud. 2006, 22, 142-160. [CrossRef]

13. Woods, M. Engaging the global countryside: Globalization, hybridity and the reconstitution of rural place. Prog. Hum. Geogr. 2007, 31, 485-507. [CrossRef]

14. Halfacree, K. Trial by space for a 'radical rural': Introducing alternative localities, representations and lives. J. Rural Stud. 2007, 23, 125-141. [CrossRef]

15. Brunori, G.; Rossi, A. Differentiating countryside: Social representations and governance patterns in rural areas with high social density: The case of Chianti, Italy. J. Rural Stud. 2007, 23, 183-205. [CrossRef]

16. Umans, L.; Arce, A. Fixing rural development cooperation? Not in situations involving blurring and fluidity. J. Rural Stud. 2014, 34, 337-344. [CrossRef]

17. Peou, C. Negotiating rural-urban transformation and life course fluidity: Rural young people and urban sojourn in contemporary Cambodia. J. Rural Stud. 2016, 44, 177-186. [CrossRef]

18. Timmermans, H.; Arentze, T.; Joh, C. Analysing space-time behaviour: New approaches to old problems. Prog. Hum. Geogr. 2002, 26, 175-190. [CrossRef]

19. Neutens, T.; Schwanen, T.; Witlox, F. The prism of everyday life: Towards a new research agenda for time geography. Transp. Rev. 2011, 31, 25-47. [CrossRef]

20. Chai, Y.W. Space-time behavior research in China: Recent development and future prospect. Ann. Assoc. Am. Geogr. 2013, 103, 1093-1099. [CrossRef]

21. Shaw, S.L.; Yu, H.; Bombom, L. A Space-Time GIS Approach to Exploring Large Individual-based Spatiotemporal Datasets. Trans. GIS 2008, 12, 425-441. [CrossRef]

22. Crease, P.; Reichenbacher, T. Linking time geography and activity theory to support the activities of mobile information seekers. Trans. GIS 2013, 17, 507-525. [CrossRef]

23. Lu, M.; Arikawa, M.; Sugiyama, A. Location-based applications using analog maps for sustainable local tourism information services. Cartographica 2018, 53, 129-145. [CrossRef]

24. Zhou, X.X.; Ding, Y.; Wu, C.B.; Huang, J.; Hu, C.D. Measuring the spatial allocation rationality of service facilities of residential areas based on internet map and location-based service data. Sustainability 2019, 11, 1337. [CrossRef]

25. Zheng, Y.; Capra, L.; Wolfson, O.; Yang, H. Urban computing: Concepts, methodologies, and applications. ACM Trans. Intell. Syst. Technol. 2014, 5, 38. [CrossRef] 
26. Liu, Y.; Liu, X.; Gao, S.; Gong, L.; Kang, C.G.; Zhi, Y. Social sensing: A new approach to understanding our socioeconomic environments. Ann. Assoc. Am. Geogr. 2015, 105, 512-530. [CrossRef]

27. Graham, M.; Shelton, T. Geography and the future of big data, big data and the future of geography. Dialogues Hum. Geogr. 2013, 3, 255-261. [CrossRef]

28. Wang, Y.X.; Dong, L.; Liu, Y.; Huang, Z.; Liu, Y. Migration patterns in China extracted from mobile positioning data. Habitat Int. 2019, 86, 71-80. [CrossRef]

29. Ding, L.; Niu, X.Y.; Song, X.D. Measuring the employment center system in Shanghai central city: A study using mobile phone signaling data. Acta Geogr. Sin. 2016, 71, 484-499. [CrossRef]

30. Huang, J.W.; Liu, X.T.; Zhao, P.X.; Zhang, J.W.; Kwan, M.P. Interactions between bus, metro, and taxi use before and after the Chinese Spring Festival. Int. J. Geo-Inf. 2019, 8, 445. [CrossRef]

31. Kang, C.G.; Qin, K. Understanding operation behaviors of taxicabs in cities by matrix factorization. Comput. Environ. Urban Syst. 2016, 60, 79-88. [CrossRef]

32. Chen, Y.; Liu, X.; Gao, W.; Wang, R.Y.; Li, Y.; Tu, W. Emerging social media data on measuring urban park use. Urban For. Urban Green. 2018, 31, 130-141. [CrossRef]

33. Donahue, M.L.; Keeler, B.L.; Wood, S.A.; Fisher, D.M.; Hamstead, Z.A.; McPhearson, T. Using social media to understand drivers of urban park visitation in the Twin Cities, MN. Landsc. Urban Plan. 2018, 175, 1-10. [CrossRef]

34. Zhang, F.; Zhou, B.L.; Ratti, C.; Liu, Y. Discovering place-informative scenes and objects using social media photos. R. Soc. Open Sci. 2019, 6, 181375. [CrossRef] [PubMed]

35. Li, X.J.; Ratti, C. Using Google street view for street-level urban form analysis, a case study in Cambridge, Massachusetts. In The Mathematics of Urban Morphology: Modeling and Simulation in Science, Engineering and Technology; D'Acci, L., Ed.; Birkhäuser: Basel, Switzerland, 2019; pp. 457-470.

36. Yuan, Y.; Wang, Y.; Zhou, X.; Zhang, X.L. Conceptual exploration and practical application on flexibility and efficiency of territory spatial planning making from the perspective of big data. China Land Sci. 2019, 33, 9-16, 23. [CrossRef]

37. Wang, J.; Lee, C. Global production networks and local institution building: The development of the information-technology industry in Suzhou, China. Environ. Plan. A 2007, 39, 1873-1888. [CrossRef]

38. Wei, Y.H.; Liefner, I.; Miao, C.H. Network configurations and R\&D activities of the ICT industry in Suzhou Municipality, China. Geoforum 2011, 42, 484-495. [CrossRef]

39. Wang, L.; Shen, J.F.; Chung, C.K.L. City profile: Suzhou-A Chinese city under transformation. Cities 2015, 44, 60-72. [CrossRef]

40. Li, Y.; Qiu, L.M. A comparative study on the quality of China's eco-city: Suzhou vs Kitakyushu. Habitat Int. 2015, 50, 57-64. [CrossRef]

41. Li, H.B.; Yuan, Y.; Zhang, X.L.; Li, Z.; Wang, Y.H.; Hu, X.L. Evolution and transformation mechanism of the spatial structure of rural settlements from the perspective of long-term economic and social change: A case study of the Sunan region, China. J. Rural Stud.. in press. [CrossRef]

42. Huang, X.; Dijst, M.; Weesep, J.V.; Jiao, Y.X. Residential choice among rural-urban migrants after Hukou reform: Evidence from Suzhou, China. Popul. Space Place 2017, 23, e2035. [CrossRef]

43. Wang, W.; Lien, D. Union membership, union coverage and wage dispersion of rural migrants: Evidence from Suzhou industrial sector. China Econ. Rev. 2018, 49, 96-111. [CrossRef]

44. Yuan, F.; Wei, Y.H.; Chen, W. Economic transition, industrial location and corporate networks: Remaking the Sunan Model in Wuxi City, China. Habitat Int. 2014, 42, 58-68. [CrossRef]

45. Wu, W.Z.; Zhang, L.P.; Qiu, F.D. Determinants of tourism ticket pricing for ancient villages and towns: Case studies from Jiangsu, Zhejiang, Shanghai and Anhui provinces. Tour. Manag. 2017, 58, 270-275. [CrossRef]

46. Liu, Z.M.; Rommel, J.; Feng, S.Y.; Hanisch, M. Can land transfer through land cooperatives foster off-farm employment in China? China Econ. Rev. 2017, 45, 35-44. [CrossRef]

47. Yang, D.Y.; Wang, H. Dilemmas of local governance under the development zone fever in China: A case study of the Suzhou region. Urban Stud. 2008, 45, 1037-1054. [CrossRef]

48. Xian, S.; Chan, R.C.K.; Qi, Z.X. Booming provincial-led north-south city-to-city cooperation in China: A case study of Suzhou-Suqian industrial park of Jiangsu province. Cities 2015, 46, 44-54. [CrossRef]

49. Long, K.S.; Wang, Y.R.; Zhao, Y.L.; Chen, L.G. Who are the stakeholders and how do they respond to a local government payments for ecosystem services program in a developed area: A case study from Suzhou, China. Habitat Int. 2015, 49, 1-9. [CrossRef] 
50. Zhu, L.L.; Zhang, C.M.; Cai, Y.Y. Varieties of agri-environmental schemes in China: A quantitative assessment. Land Use Policy 2018, 71, 505-517. [CrossRef]

51. Zhang, X.M. Research on the development strategies of rural tourism in Suzhou based on SWOT analysis. Energy Procedia 2012, 16, 1295-1299. [CrossRef]

52. Yao, Y.; Liu, X.P.; Li, X.; Zhang, J.B.; Liang, Z.T.; Mai, K.; Zhang, Y.T. Mapping fine-scale population distributions at the building level by integrating multisource geospatial big data. Int. J. Geogr. Inf. Sci. 2017, 31, 1-25. [CrossRef]

53. Horanont, T.; Phithakkitnukoon, S.; Leong, T.W.; Sekimoto, Y.; Shibasaki, R. Weather effects on the patterns of people's everyday activities: A study using GPS traces of mobile phone users. PLoS ONE 2013, 8, e81153. [CrossRef] [PubMed]

54. Widhalm, P.; Yang, Y.X.; Ulm, M.; Athavale, S.; González, M.C. Discovering urban activity patterns in cell phone data. Transportation 2015, 42, 597-623. [CrossRef]

55. Merriman, P. Mobility, Space and Culture; Routledge: London, UK, 2012; p. 1.

56. Milbourne, P. Re-populating rural studies: Migrations, movements and mobilities. J. Rural Stud. 2007, 23, 381-386. [CrossRef]

57. Halfacree, K. Heterolocal identities? Counter-urbanisation, second homes, and rural consumption in the era of mobilities. Int. J. Popul. Geogr. 2012, 18, 209-224. [CrossRef]

58. Mohíno, I.; Solís, E.; Urena, J. Changing commuting patterns in rural metro-adjacent regions: The case of Castilla-La Mancha in the context of Madrid, Spain. Reg. Stud. 2017, 51, 1115-1130. [CrossRef]

59. Milbourne, P.; Kitchen, L. Rural mobilities: Connecting movement and fixity in rural places. J. Rural Stud. 2014, 34, 326-336. [CrossRef]

60. Gieling, J.; Vermeij, L.; Haartsen, T. Beyond the local-newcomer divide: Village attachment in the era of mobilities. J. Rural Stud. 2017, 55, 237-247. [CrossRef]

61. Aure, M.; Førdea, A.; Magnussen, T. Will migrant workers rescue rural regions? Challenges of creating stability through mobility. J. Rural Stud. 2018, 60, 52-59. [CrossRef]

62. Wei, Y.H.; Gu, C.L. Industrial development and spatial dtructure in Changzhou city, China: The restructuring of the Sunan model. Urban Geogr. 2010, 31, 321-347. [CrossRef]

63. Wei, Y.H. Beyond the Sunan model: Trajectory and underlying factors of development in Kunshan, China. Environ. Plan A 2002, 34, 1725-1747. [CrossRef]

64. Tu, S.S.; Long, H.L.; Zhang, Y.N.; Ge, D.Z.; Qu, Y. Rural restructuring at village level under rapid urbanization in metropolitan suburbs of China and its implications for innovations in land use policy. Habitat Int. 2018, 77, 143-152. [CrossRef]

65. Rigg, J. Land, farming, livelihoods, and poverty: Rethinking the links in the rural South. World Dev. 2006, 34, 180-202. [CrossRef]

66. Wilson, G.A. Community resilience, globalization, and transitional pathways of decision-making. Geoforum 2012, 43, 1218-1231. [CrossRef]

67. Liu, Y.G.; Li, Z.G.; Jin, J. Pseudo-urbanization or real urbanization? Urban China's mergence of administrative regions and its effects: A case study of Zhongshan city, Guangdong Province. China Rev. 2014, 14, 37-59. [CrossRef]

68. Liu, Y.S.; Li, Y.H. Revitalize the world's countryside. Nature 2017, 548, 275-277. [CrossRef]

(C) 2019 by the authors. Licensee MDPI, Basel, Switzerland. This article is an open access article distributed under the terms and conditions of the Creative Commons Attribution (CC BY) license (http://creativecommons.org/licenses/by/4.0/). 